\title{
IAMJ
}

INTERNATIONAL

AYURVEDIC

MEDICAL JOURNAL

ISSN: $2320-5091$

Impact Factor: 6.719

\section{IMPORTANCE OF AYURVEDIC DIET IN DIFFERENT AGE GROUPS OF CHILDREN}

\author{
Vikash Kumar Gujral ${ }^{1}$, Dinesh Kumar Rai ${ }^{2}$, Prem Prakash Vyas ${ }^{3}$, Sonam Boyal ${ }^{4}$ \\ ${ }^{1}$ MD Scholar, PG Department of Kaumarbhritya, Dr. Sarvapalli Radhakrishanan Rajasthan \\ Ayurved University Jodhpur (Raj.), India \\ ${ }^{2}$ Assistant Professor, PG Department of Kaumarbhritya, Dr. Sarvapalli Radhakrishanan \\ Rajasthan Ayurved University Jodhpur (Raj.), India \\ ${ }^{3}$ Associate Professor \&amp; HOD, PG Department of Kaumarbhritya, Dr. Sarvapalli \\ Radhakrishanan Rajasthan Ayurved University Jodhpur (Raj.), India \\ ${ }^{4}$ MD Scholar, PG Department of Kaumarbhritya, Dr. Sarvapalli Radhakrishanan Rajasthan \\ Ayurved University Jodhpur (Raj.), India
}

Corresponding Author: luckygujral1992@gmail.com

\section{https://doi.org/10.46607/iamj2109102021}

(Published Online: October 2021)

Open Access

(C) International Ayurvedic Medical Journal, India 2021

Article Received: 13/09//2021 - Peer Reviewed: 22/09/2021 - Accepted for Publication: 24/09/2021

\section{Check for updates}

\section{ABSTRACT}

Ayurveda is a science of life that focuses on promoting and maintaining people's health. Lifestyle and diet are key elements impacting an individual's health in this technological and competitive day. Diet and dietary habits play important role in the maintenance of health. Nutrition offers the building elements for the development of new dhatus. Dhatus are energy reservoirs that come in a variety of shapes and sizes. Dhatus are continually being broken down to extract energy. So, replenishing good quality Dhatus is essential. For this, balanced foods are important. In Ayurveda, eating foods are energizing the Mind. It's Sattvic, Rajasic or Tamasic gunas depend on the food we consume. Let my food be my medicine. Health depends solely on the food we intake. Strength, health, \& life depend on Agni. But Agni is also constantly replenished from the nutrition. So, to maintain Sama Agni eating balanced foods are essential. Toddlers \& Pre-schoolers need adequate intake to achieve full growth and develop- 
mental potential. Undernutrition impairs children's cognitive development as well as their ability to explore their environments.

Keywords: Aahar, Agni, Ayurveda, Dhatus, Growth, Nutrition,

\section{INTRODUCTION}

Ayurveda is a science of life that focuses on promoting and maintaining people's health ${ }^{1}$. Nutrition plays a central role in Ayurvedic living. Ahara \{Diet\} Nidra \{Sleep\} and Brahmacharya \{Abstinence\} are recognized as the three Upasthambhas \{sub-pillars\} essential for the smooth running of life $^{2}$. Among the three Upasthambhas, Ahara is considered the best sustainer of life ${ }^{3}$. From the earliest stages of fetal development, at birth, through infancy, childhood, adolescence, and on into adulthood and old age, proper food and good nutrition are essential for survival, physical growth, mental development, performance $\&$ productivity, health, and well-being. In Ayurveda a balanced diet is planned in relation to the known Panchabhautic composition and Tridoshic impacts in the living human body. Food (Ahara) and lifestyle (Vihara) significant affect one's overall health and the upsurge of metabolic and degenerative diseases are the results of adaptation of modern life style ${ }^{4}$ According to Acharya Kashyap, Ahara is considered as the Mahabhaishajya i.e., the great medicine. Showing the importance of food Acharya Charaka says that food sustains the life of all living beings and complexion, clarity, good voice, longevity, genius, happiness, satisfaction, nourishment strength and intellect are all conditioned by food ${ }^{5}$. The right quantity is defined as the amount of food that is digested and processed in a timely manner without disrupting the body's equilibrium (of dhatus or dohas). Chakrapani the commentator of Charaka samhita opines those light foods are Vayu Agnimahabhuta predominant while heavy food substances are Prithvi \& Jala mahabhuta predominant ${ }^{6}$. Nutrition's provides building blocks to create new Dhatus. Dhatus are the reservoir of energy in different forms. Dhatus are constantly broken down to utilize energy. So, replenishing good quality Dhatus is essential. For this, balanced food is important. Ahara is categorized as Hitahara (whole- some) and Ahitahara (unwholesome). In a similar context, the terms Pathya and Apathya are also used to denote the acceptability and adaptability of a particular food in each context. Acharya Charaka gives a list of dietetics that should be and should not be taken regularly ${ }^{7}$. Let my food be my medicine. Toddlers and Pre-schoolers need adequate intake to achieve full growth and developmental potential. Children's cognitive development and ability to explore their surroundings are both hampered by malnutrition. With sufficient nutrition and environmental assistance, the long-term repercussions of undernutrition (cognitive impairment) can be avoided or alleviated.

\section{In Ayurveda importance of nutrition-}

Acharya Charaka has said the source of life for all living beings is food \& all living beings are food \& all the world seeks food. Complexion, clarity, good voice, long life, understanding, happiness, satisfaction, growth, strength \& intelligence are all established in nutrition. Whatever is beneficial for worldly happiness, whatever belongs to the Vedic sacrifices leading to heaven $\&$ whatever actions lead to spiritual salvation are said to be established through nutrition ${ }^{8}$. the child nutrition begins before birth only. Poor nutrition during pregnancy may stunts fetal growth and leads poor brain development. Even after birth, the child growth depends on the mother diet, later period on own diet. So, the right diet and lifestyle from early years leave a permanent impact on the child physical and mental wellbeing. In Ayurveda, children are classified into 3 groups as per their $\operatorname{diet}^{9}$

which are as follows:

1. Ksheerap Awastha- Up to 1 year of lifeconsuming only breast milk ${ }^{10}$.

2. Ksheerannada Awastha- Up to 2 years of life along with milk child is consuming solid food ${ }^{11}$. 
3. Annad Awastha- After 2 years of life where child consumes all like adult ${ }^{12}$.

Diet According to Different Age Group (Awastha) of Child

\section{Ahara in Ksheerap Awastha-}

For a newborn, breast milk (Stanya) is considered as Amrita and Ayurveda praise breastfeeding i.e., Stanyapana. Most of the Acharyas told exclusive breastfeeding up to 6 months. Mother milk contains the exact proportion of fat, cholesterol, protein, and carbohydrates for a baby. Mother's milk is not only the perfect nutritional choice; it also protects against several diseases. So, it is exclusively advised at the early age of the child. The mother should start feeding the child from the first day only ${ }^{13}$. First three days there is the secretion of Piyush, which is necessary for the development of immunity in children. According to Acharya Kashyapa breastfeed result in good growth, strength, longevity, and good health of the child as well as not causing any trouble or disease to the child ${ }^{14}$.

\section{Ahara in Ksheerannada Awastha-}

From 6 months up to 2 years are considered in Ksheerannada awastha. Around six months the baby begins to grow teeth. Once the teeth begin to come in the baby is given a sign that it is ready to eat food other than milk. Hence, Acharya Kashyapa told Phalaprashana samskara at the age of 6 months.

\section{Phalaprashana Samskara-}

It is performed at 6 months ${ }^{15}$ and fruits are given to newborns as a supplement. Vitamin C, D, and iron are lacking in mother's milk and must be supplemented by the infants. These nutrients are abundant in fruit juices. Fruit juices, in addition to Agni vridhi, help to supplement extra nourishment, ease constipation, and keep children hydrated.

\section{Annaprashana Samskara-}

After 6 months, children require concentrated energydense foods to maintain an adequate rate of growth. Child teeth begin to erupt, a biting movement begins, and the tendency to push solids out of the mouth decreases and the digestive system is mature enough to digest food. As the birth weight doubles, breast milk alone is no longer sufficient to provide nutritional needs. ${ }^{16}$.

\section{Ahara in Annada Awastha-}

A child from the age of 2 years is considered in $A n$ nada Awastha. ${ }^{17}$ In this Awastha child should be shifted on the cereals. All types of food with all forms i.e., Lehya, Peya, Bhojya etc can be given in this Awastha of children life.

\section{CLASSIFICATIONS OF BASIC FOODS IN AYURVEDA: -}

Ayurveda classifies food (Ahara) into 12 basic categories based on source, method of preparation and utility such as-

1. Sukadhanya (corns/ carbohydrate, polysaccharide)

2. Samidhanya (pulses/ vegetable proteins)

3. Mamsa (meat/ First class proteins)

4. Saka (vegetables/Minerals)

5. Phala (fruits/Vitamins)

6. Harita (salads/ Food adjuvant)

7. Madya (fermented drinks/ Alcohol, carbohydrate, monosaccharide)

8. Ambu (water)

9. Gorasa (milk and milk products)

10. Iksuvikara (products of sugarcane)

11. Krtanna (food preparations)

12. Aharayogi (accessory food articles).

Also, the convenience of consumption shows the way to classify food articles into different forms as cited in Charaka Samhita ${ }^{18}$. The Ayurvedic texts give great emphasis on the compatibility and incompatibility of certain foods. Charaka describes in detail the 18-fold denominators of Viruddhahara, i.e., dietary incompatibility ${ }^{19}$. Ahara dravyas become incompatible due to their mutually contradictory qualities, by combinations (Samyoga), by the method of preparation (Samskara), by virtue of place (Desha), time (kala), dose (Matra) and some others by their inherent nature $(\text { Swabhava })^{20}$. Charaka mentions that the intake of incompatible diet is responsible for the causation of sterility, blindness, Visarpa (Herpes), Udara (Ascites), insanity, fistula in ano or fainting, intoxication, abdominal distention, stiffness in neck, varieties of anemia, indigestions, various skin diseases, diseases 
of intestines, swelling, gastritis, fever, rhinitis, and infertility $^{21}$. Ayurveda emphasizes the material quality of food but places even greater emphasis on the selection of food, its processing and cooking, and rules for healthy eating. Thus, the Ayurvedic approach to food and dietetics is very different from the conventional Western approach. Charaka samhita describes the eight principles of Ahara vidhi i.e.,

(1) Prakriti (nature of food articles)

(2) Karana (preparation)

(3) Samyoga (combinations)

(4) Rashi (quantity)

(5) Desha (habitat and climate)

(6) Kala (time factor)

(7) Upayogasamstha (rules of use)

(8) Upayokta (the user) ${ }^{22}$

While considering Ahara matra, Acharya Charaka says that food is to be taken depending upon the power of digestion and metabolism (Agnibala and srotobala), which varies according to season as well as the age of the individual. The quantity of the food to be taken directly depends on the digestive strength of a person (Agnibala). The stomach capacity is divided into three portions and two portions should be filled with solid and liquid food and one portion should be left for easy gastric movements and air, to aid the digestion process ${ }^{23}$. During the process of eating, water taken in small quantity stimulates digestion, and when taken after a meal causes Sthaulya (obesity) ${ }^{24}$.

Processing of food results in the transformation of attributes of the dravya. Methods of preparing different types of food items like Manda (rice water which is the clear supernatant watery portion (without rice) in which rice is boiled) Peya (rice soup), Yavaagu (semi-solid meal thicker than Peya), Vilepi (thick rice soup which thicker than Yavaagu) Yusha (Lentil soup), are mentioned in the samhitas. The different Ahara kalpanas of the same dravya differ in their properties and digestibility. The human body is the result of consumables taken in four forms i.e. Ashita (eatables), Peeta (liquid food), Leedha (masticable foods) \& Khadita (linctus) and leedha (Masticable) ${ }^{25}$.

\section{DISCUSSION}

Our health depends solely on the food we intake. Strength, health, \& our life depend on Agni. But Agni is also constantly replenished from the food we eat. So, to maintain "Sama Agni" eating balanced food is essential. Balanced foods are important Let my food be my medicine Nutrition is a fundamental pillar of human life, health, and development across the entire life span. Most incurable diseases are produced due to improper nutrition. An intelligent and selfcontrolled person should consume conductive food in the right quantity and at right time to prevent diseases for proper maintenance of positive health, one should, first, eat food in proper quantity. The quantity of food to be taken again depends on the pattern of digestion. The powers of digestion and metabolism again vary according to the season as well as the age of the individual. The eating habits established now impact food habits and health later in life. The standard measurement of food for an individual is to be determined based on one's digestive capacity. Longterm effects of undernutrition (cognitive impairment) may be prevented or reduced with adequate nutrition and environmental support.

\section{CONCLUSION}

Ayurveda lays a great deal of emphasis upon proper diet for the preservation \& promotion of positive health, and prevention and cure of diseases. For all disease wholesome and unwholesome (pathya and apathya) food ingredients have been specified. If a person suffering from any disease follows strictly the regulations of diet. Food taken in proper quantity provides strength, vigour, good complexion and nurtures the health of the tissues. To live healthily, one must live in harmony with his surroundings and follow a diet suitable to one's bodily constitution. Up to the age of the 1-year child should exclusively on milk while up to the 2 years we should give the Peya and Lehya Ahara along with the milk and after the 2 years children can eat all the form of Ahara which is important in the growth and development of the child. 


\section{REFERENCES}

1. Sastri SN; Charka Samhita, Sutrasthana 30/26, Chaukhambha Bharati Academy Varanasi: Reprinted 2013.

2. Sastri SN; Charka Samhita, Sutrasthana 11/35, Chaukhambha Bharati Academy Varanasi: Reprinted 2013.

3. Sastri SN; Charka Samhita, Sutrasthana 25/40, Chaukhambha Bharati Academy Varanasi: Reprinted 2013.

4. Sastri SN; Charka Samhita, Sutrasthana 27/349-351, Chaukhambha Bharati Academy Varanasi: Reprinted 2013.

5. Sastri SN; Charka Samhita, Sutrasthana 27/349-351, Chaukhambha Bharati Academy Varanasi: Reprinted 2013.

6. Sastri SN; Charka Samhita, Sutrasthana 5/6, Chaukhambha Bharati Academy Varanasi: Reprinted 2013.

7. Sastri SN; Charka Samhita, Sutrasthana 5/12, Chaukhambha Bharati Academy Varanasi: Reprinted 2013.

8. Sastri SN; Charka Samhita, Sutrasthana 27/349-350, Chaukhambha Bharati Academy Varanasi: Reprinted 2013.

9. Shastri Dr. Ambikadutta Sushurta Samhita, Sutrasthana 35/34, Chaukhamba Sanskrita Sansthana, Varanasi: Reprinted 2014

10. Shastri Dr. Ambikadutta Sushurta Samhita, Sutrasthana 35/34, Chaukhamba Sanskrita Sansthana, Varanasi: Reprinted 2014

11. Shastri Dr. Ambikadutta Sushurta Samhita, Sutrasthana 35/34, Chaukhamba Sanskrita Sansthana, Varanasi: Reprinted 2014

12. Shastri Dr. Ambikadutta Sushurta Samhita, Sutrasthana 35/34, Chaukhamba Sanskrita Sansthana, Varanasi: Reprinted 2014

13. Sastri SN; Charka Samhita, Sharirasthana 8/46, Chaukhambha Bharati Academy Varanasi: Reprinted 2013.

14. Sharma Pandit Hemraj Kashyapa Samhita Khilsthana 5/9, Chaukhamba Sanskrita Sansthana, Varanasi, Reprint 2018

15. Sharma Pandit Hemraj Kashyapa Samhita Khilsthana 5/9, Chaukhamba Sanskrita Sansthana, Varanasi, Reprint 20

16. Ghai O P Ghai Essential Pediatrics CBS Publisher and Distributors New Delhi, Reprint 2019 page.no.91

17. Shastri Dr. Ambikadutta Sushurta Samhita, Sutrasthana 35/34, Chaukhamba Sanskrita Sansthana, Varanasi: Reprinted 2014

18. Sastri SN; Charka Samhita, Sutrasthana 27/6,7 Chaukhambha Bharati Academy Varanasi: Reprinted 2013.
19. Sastri SN; Charka Samhita, Sutrasthana 26/86-87 Chaukhambha Bharati Academy Varanasi: Reprinted 2013.

20. Sastri SN; Charka Samhita, Sutrasthana 26/102-103 Chaukhambha Bharati Academy Varanasi: Reprinted 2013.

21. Sastri SN; Charka Samhita, Sutrasthana 26/102-103 Chaukhambha Bharati Academy Varanasi: Reprinted 2013.

22. Sastri SN; Charka Samhita, Sutrasthana 1/21 Chaukhambha Bharati Academy Varanasi: Reprinted 2013.

23. Sastri SN; Charka Samhita, Sutrasthana 2/3 Chaukhambha Bharati Academy Varanasi: Reprinted 2013.

24. Sastri SN; Charka Samhita, Sutrasthana 6/17 Chaukhambha Bharati Academy Varanasi: Reprinted 2013.

25. Sastri SN; Charka Samhita, Sutrasthana 28/3 Chaukhambha Bharati Academy Varanasi: Reprinted 2013.

\section{Source of Support: Nil \\ Conflict of Interest: None Declared}

How to cite this URL: Vikash Kumar Gujral et al: Importance Of Ayurvedic Diet In Different Age Groups Of Children. International Ayurvedic Medical Journal \{online\} 2021 \{cited October 2021\} Available from: http://www.iamj.in/posts/images/upload/2428_2432.pdf 